\title{
Food sensitisation patterns measured by ISAC multiplex assay in the Netherlands
}

\author{
Mark Blankestijn", Rob Klemans, Henny Otten, Heike Rockmann, Carla Bruijnzeel-Koomen, Edward Knol, \\ André Knulst
}

From Food Allergy and Anaphylaxis Meeting 2014

Dublin, Ireland. 9-11 October 2014

\section{Background}

Component-resolved diagnostics is increasingly used in food allergy diagnostics. In a Dutch tertiary patient population we determined the sensitization patterns and protein families involved in our population using the multiplex Immuno-Solid phase Allergen Chip (ISAC).

\section{Methods}

Multiplex ISAC tests were performed in case of suspicion of (extensive) poly-sensitization in patients referred for food allergy and/or atopic eczema. Patient history of 40 random patients who have had an ISAC was analysed to determine the clinical value of the ISAC.

\section{Results}

Of 943 ISAC tests, 852 showed sensitization to at least one component and were included for further analysis. Mean age was 33,4 years. The majority of patients in our population was poly-sensitized, with $66 \%$ recognizing more than ten components. The most recognized component was Bet v 1 (70\%). The top 10 food allergens were: apple (Mal d 1;65\%), peach (Pru p 1;63\%), hazelnut (Cor a $1.0401 ; 63 \%$ ), peanut (Ara h 8; 56\%, Ara h 6; $23 \%$, Ara h 2; $15 \%$ ), soy (Gly m 4; 39\%), celery (Api g 1; 25\%), kiwi (Act d 8; 20\%) and walnut (Jug r 2; 15\%). $84 \%$ showed sensitization to one or more food allergens. Within this group, $84 \%$ recognized at least one PR-10 component, followed by storage proteins (35\%) and non-specific lipid transfer proteins (nsLTP; 12\%). The prevalence of sensitization to cross-reactive carbohydrate determinants (CCD) within the entire population was $9 \%$. Sensitization to at least one food components of animal origin (cow's milk/egg) was seen in 19\% of all cases, with Bos $d 8$ recognized most frequently (8.1\%).

University Medical Center Utrecht, Utrecht, The Netherlands
The ISAC seems to support clinical suspicion of food allergy in most cases, although sensitization together with a negative patient history is common.

\section{Conclusions}

Bet $\mathrm{v} 1$ is the allergen component recognized the most, followed closely by other PR-10 family proteins from plant foods. Sensitization to food components of animal origin was seen in $19 \%$ of the patients.

Published: 30 March 2015

doi:10.1186/2045-7022-5-S3-P126

Cite this article as: Blankestijn et al:: Food sensitisation patterns

measured by ISAC multiplex assay in the Netherlands. Clinical and Translational Allergy 2015 5(Suppl 3):P126.

Submit your next manuscript to BioMed Central and take full advantage of:

- Convenient online submission

- Thorough peer review

- No space constraints or color figure charges

- Immediate publication on acceptance

- Inclusion in PubMed, CAS, Scopus and Google Scholar

- Research which is freely available for redistribution 